\title{
DE
} DE GRUYTER OPEN

Arch. Min. Sci. 62 (2017), 1, 215-224

Electronic version (in color) of this paper is available: http://mining.archives.pl

DOI 10.1515/amsc-2017-0016

\author{
CHENG JING-YI**, ZHANG YI-DONG*, CHENG LIANG**, JI MING**1, GU WEI*, \\ GAO LIN-SHENG***
}

\section{STUDY OF LOADING AND RUNNING CHARACTERISTIC OF HYDRAULIC SUPPORT IN UNDERHAND MINING FACE}

\section{BADANIE OBCIĄŻENIA I DZIALANIA PODPÓR HYDRAULICZNYCH W PRZODKU NACHYLONYM}

\begin{abstract}
According to complex geological conditions of working face E1108 in Xin-ji mine \#2, loading and running characteristic of hydraulic support, influence of depression angle on mining pressure behaviors, as well as relation between advancing speed and the support loading were measured and analyzed. The results indicate that depression angle is inversely proportional to support resistance, in other words, larger depression angle area coincides with lower support resistance area. Moreover, support resistance is generally high when working face advancing speed is slow. Technologies for controlling hydraulic support stability such as improving advancing speed properly, controlling mining height and increasing support resistance are put forward based on research.
\end{abstract}

Keywords: diclinic working face; large depression angle; running characteristic of support; stability of support

Z uwzględnieniem złożonych warunków geologicznych w scianie E1108 w kopalni Xin-Ji \#2 dokonano pomiarów i analiz obciążenia i działania podpór hydraulicznych, zbadano wpływ kąta depresji na wielkość ciśnienia poziomu wydobywczego, a także zależność pomiędzy szybkością posuwania się na przodku i obciążeniem podpór. Wyniki analiz wskazują, że kąt depresji jest odwrotnie proporcjonalny do wytrzymałości podpory. Przy większych wartościach kąta depresji mamy do czynienia z obszarem gdzie wytrzymałość podpór jest niższa. Ogólnie rzecz biorąc, wytrzymałość podpory jest zazwyczaj wysoka dla niewielkich prędkości posuwania się na przodku. W pracy przedstawiono metody kontroli stabilności podpór hydraulicznych poprzez regulację szybkości posuwania się przodka, regulację wysokości wybierania oraz poprzez zwiększenie wytrzymałości podpór.

Słowa kluczowe: przodek nachylony, kąty depresji, charakterystyka pracy podpory hydraulicznej, stabilność podpory

* STATE KEY LABORATORY OF COAL RESOURCES AND SAFE MINING, SCHOOL OF MINES, CHINA UNIVERSITY OF MINING \& TECHNOLOGY, 221116, XUZHOU, CHINA

** SCHOOL OF MINES; KEY LABORATORY OF DEEP COAL RESOURCE MINING, MINISTRY OF EDUCATION OF CHINA; CHINA UNIVERSITY OF MINING \& TECHNOLOGY, 221116, XUZHOU, CHINA

*** NORTH CHINA INSTITUTE OF SCIENCE \& TECHNOLOGY, 101601,YANJIAO BEIJING-EAST, CHINA

1 CORRESPONDING AUTHOR, E-mail: jiming@cumt.edu.cn 


\section{Introduction}

Under condition of big angle diclinic working face arranged along inclination and advanced along strike direction, due to the impact caused by the geologic structure including folding, mining process will successively experience underhand stoping (or overhand stoping) and overhand stoping (or underhand stoping). Compared to nearly flat or slightly inclined seam mining, because of the larger dip angles of working face in inclination and strike direction periodic roof weighting step during underhand stoping is longer than that during overhand stoping and support resistance varies significantly with depression angle. Navid Hosseini et al. (2012), Gholamreza Saeedl et al. (2013) analyzed the stress distribution of longwall face by using numerical methods. Feng Zhijiang et al. (2010) had analyzed roof weighting step of diclinic working face by monitoring mining pressure. The trend that support resistance reducing with depression angle increasing was discovered from his work. Zhang Yidong et al. (2010) had set up thin plate mechanical model of underhand/overhand mining roof with big dip angle and the results showed that roof rupture pattern of underhand/overhand mining was obviously affected by dip angle which was different from O-X break type of nearly flat seam roof.

Since depression angle has an important influence on cover rock movement and fully-mechanized mining equipment, support stability is generally poor in large depression angle working face. As a result, the working face usually slides downward or topples toward coal seam due to sliding force of gravity and gangue thrust. Moreover, shearer unstable running may cause slipper abrasion failure, scraper conveyor leaning forward or poor coal loading efficiency. Previous research mainly focused on analysis of measured data and mining equipment management (Liu W.Q. \& Zhu L., 2009; Li X.Y. \& Chen P.H., 2004; Wu Z.J. \&Ye H.Z., 2008), systemic analysis on relations between working face depression angle and support resistance, advancing speed and support loading have been seldom studied. In this paper, actual measuring and monitoring analysis of hydraulic support running condition based on large depression angle working face of Xinji mine \#2, E1108 were carried out to analyze the hydraulic support loading and running characteristic, the result can provide the reference to safe and efficient underhand mining with big depression angle.

\section{General situation of working face}

Working face E1108 is located in the east mining area of Xinji Mine \#2. The underground elevation is $-464.9 \sim-607.0 \mathrm{~m}$ and the strike length of working face is $944-935 \mathrm{~m}$ (average $940 \mathrm{~m}$ ). The inclination length is $110 \sim 127 \mathrm{~m}$ and the working face is arranged in seam 11-2 which consists of three coal seams and two partings. Seam thickness is 2.2 3.6 m (average $2.83 \mathrm{~m}$ ). Immediate roof is mudstone and main roof from bottom to top is fine sandstone, thin coal seam, mudstone, sandy mudstone in turn. Immediate floor is mudstone and main floor is fine sandstone. Dip angle is $10 \sim 45^{\circ}$ (average $32^{\circ}$ ). Seam of working face is fold and shows low wave shape closed to pan bottom, the former section is diagonal underhand stoping (depression angle is $15^{\circ} \sim 36^{\circ}$, average is $27^{\circ}$ ), the later section is diagonal overhand stoping (inclination angle is $10^{\circ} \sim 30^{\circ}$, average is $25^{\circ}$ ). Dip angle in inclination and strike direction during underhand stoping is large, which will have an important influence on law of mining pressure behavior and stability of fully mechanized equipment such as hydraulic support. 
During observing and measuring, distribution of angles in inclination and strike direction is shown in Table 1. Forward distance is $109 \mathrm{~m}$ in wind way and $112 \mathrm{~m}$ in conveying roadway. Support is ZZ7600/18/38 shield-hydraulic type, whose designed running resistance is $7600 \mathrm{kN}$ setting loading is $6185 \mathrm{kN}$.

TABLE 1

Angles changes of in inclination and strike direction during observing

\begin{tabular}{|c|c|c|c|c|c|}
\hline Date & $\begin{array}{c}\text { Transport } \\
\text { tunnel } \\
\text { DA } / \mathbf{I A}\left[^{\circ}\right]\end{array}$ & $\begin{array}{l}\text { The middle } \\
\text { of the face } \\
\text { DA/IA }\left[{ }^{\circ}\right]\end{array}$ & $\begin{array}{c}\text { Return } \\
\text { airway } \\
\text { DA/IA }\left[^{\circ}\right] \\
\end{array}$ & $\begin{array}{c}\text { Accumulated advance } \\
\text { distance of the return } \\
\text { airway }[\mathrm{m}]\end{array}$ & $\begin{array}{c}\text { Accumulated advance } \\
\text { distance of the transport } \\
\text { tunnel }[\mathrm{m}]\end{array}$ \\
\hline 2010-04-10 & $25 / 17$ & $15 / 13$ & $10 / 15$ & 0 & 0 \\
\hline 2010-04-16 & $25 / 17$ & $15 / 14$ & $10 / 13$ & 13 & 8 \\
\hline $2010-04-21$ & $30 / 25$ & $16 / 16$ & $12 / 17$ & 25 & 20 \\
\hline 2010-04-28 & $33 / 24$ & $25 / 19$ & $16 / 22$ & 41 & 29 \\
\hline 2010-05-05 & $32 / 25$ & $26 / 21$ & $17 / 20$ & 53 & 47 \\
\hline $2010-05-12$ & $26 / 20$ & $20 / 23$ & $16 / 26$ & 67 & 64 \\
\hline $2010-05-13$ & $34 / 22$ & $30 / 25$ & $15 / 26$ & 70 & 67 \\
\hline 2010-05-19 & $27 / 25$ & $20 / 26$ & $15 / 25$ & 80 & 79 \\
\hline $2010-05-26$ & $25 / 21$ & $18 / 26$ & $16 / 29$ & 95 & 93 \\
\hline 2010-06-01 & $18 / 28$ & $15 / 31$ & $14 / 26$ & 109 & 112 \\
\hline
\end{tabular}

\section{Relation analysis between depression angle and support loading}

In order to observe hydraulic support resistance and running characteristic, 6 lines were arranged from bottom $8^{\text {th }}$ support to top of working face, and the spacing between 2 lines is 10 supports $(15 \mathrm{~m})$. There is a KBJ-60III-1 continuous recorder of support running resistance on each line.

\subsection{Analysis of depression angle influence on running resistance}

During observing and measuring, most of geological conditions are basically stable except that depression angle changes greatly, which can be seen in Fig. 1. It is helpful to look into the influence of depression angle on mining pressure. Give the condition of same location and dip angle in inclination, as well as similar seam thickness and mining technology, support running resistance with different depression angle is analyzed in Table 1. It is obvious that depression angle has some significant influence on support resistance and the former is inversely proportional to the latter, which means that when depression angle increases, support resistance drops. In addition, as shown in Fig. 2(a) diagram for depression angle distribution characteristics of working face during whole mining process is drawn via MATLAB. Fig. 2(b) shows support resistance distribution characteristics. By selecting data at same point in area $\mathrm{A}(\mathrm{B})$ and the corresponding $\mathrm{A}^{\prime}\left(\mathrm{B}^{\prime}\right)$, relation of depression angle and support resistance can be obtained, which can be seen in Table 2 . 
Relation between depression angle and support resistance in MATLAB

\begin{tabular}{|c|c|c|c|c|c|c|}
\hline \hline Area & \multicolumn{3}{|c|}{ A } & \multicolumn{3}{c|}{ B } \\
\hline depression angle $\left[{ }^{\circ}\right]$ & 32 & 30 & 28 & 32 & 30 & 28 \\
\hline support resistance $[\mathrm{kN}]$ & 3130 & 4234 & 5065 & 3544 & 4327 & 5214 \\
\hline
\end{tabular}

It is concluded from above analysis that support resistance grows less as depression angle becomes larger.

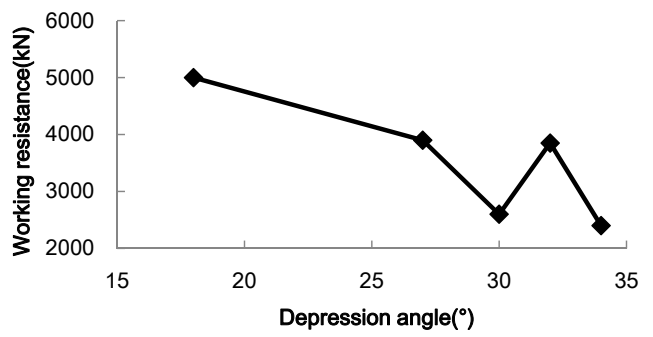

(a) Upper section (depression angle is $25^{\circ}$ )

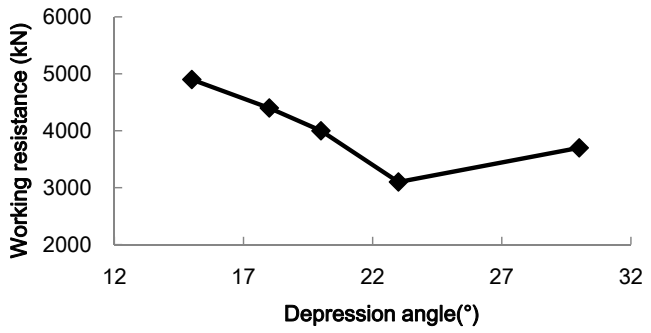

(b) Middle section (depression angle is $25^{\circ}$ )

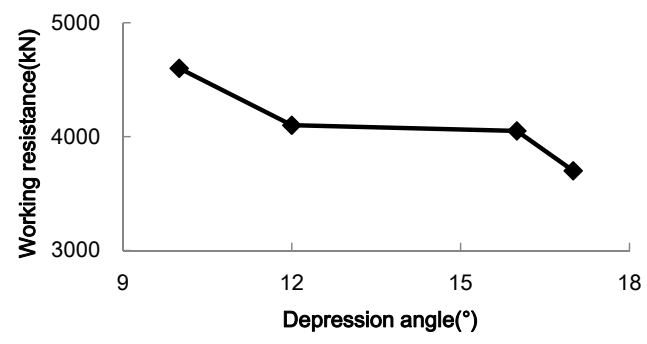

(c) Lower section (depression angle is $18^{\circ}$ )

Fig. 1. Curves of depression angle to support resistance

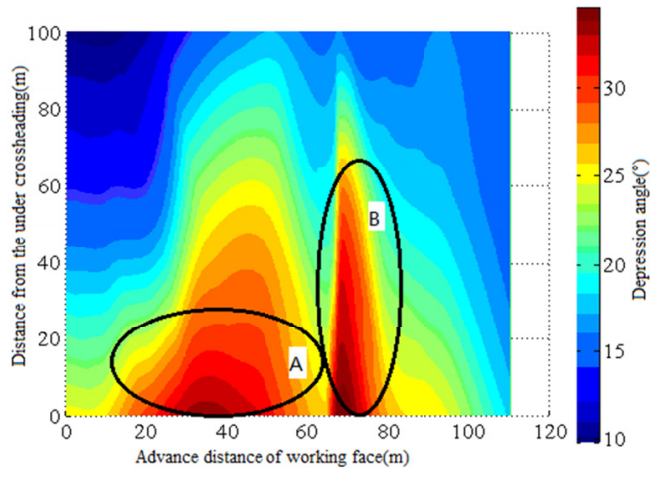

(a) Depression angle distribution diagram



(b) Support resistance distribution diagram

Fig. 2. Distribution characteristics comparison of depression angle to support resistance 
The changing of depression angle also causes the two different running resistance distribution characteristics during mining and measuring. A limit value exists in the changing of depression angle, in other words, depression angle is considered as a main factor to law of roof activities when it reaches a limit value. While depression angle increases resistance decreases greatly. If depression angle of working face is small, its pressure behavior law will be similar to that on general mining face, in this case, classical theory for roof behavior would play a leading role (Zhang Z.Y., 2007; Liu C.Y. et al., 2009; Qin B.T. et al., 2009).

\subsection{Rupture mechanism of overlying strata during big angle underhand stoping}

According to geological condition of Xinji Mine \#2, when depression angle is large, working face is very easy and inclined to form voussoir beam structure because of the roof extrusion caused by horizontal force, which can be seen Fig. 3. Occlusal equilibrium conditions between broke blocks of overlying strata is below:

$$
f\left[\left(T_{a}+R_{a}\right) \cos \theta-Q_{a} \sin \theta\right]>\left(T_{a}+R_{a}\right) \sin \theta+Q_{a} \cos \theta
$$

It should meet the following:

$$
\tan (\phi-\theta)>\frac{Q_{a}}{\left(T_{a}+R_{a}\right)}
$$

where

$f$ - friction coefficient between broke blocks;

$T_{\alpha}$ - lateral thrust force along roof;

$R_{\alpha}$ - force between blocks caused by weight;

$Q_{\alpha}$ — shearing force between two blocks, consisting of weight and loading.

When $a$ or approaches to zero, which means under the condition horizontal or gently inclined working face, $R_{a}$ is very close to zero, the equilibrium condition is listed below:

$$
\tan (\phi-\theta)>\frac{Q_{a}}{T_{a}}
$$

Normally, there is:

$$
\frac{Q_{a}}{\left(T_{a}+R_{a}\right)}>\frac{Q_{a}}{T_{a}}
$$

Given the same technical condition, it is more possible to form voussoir beam structure on overlying strata in big angle underhand stoping than in nearly flat or slightly inclined stoping. Immediate roof bears a part of overlying strata weight which relieves some pressure of support and minus support resistance, at the same time, when depression angle increases, vertical stress of support decreases and horizontal stress increases. As a result, fall and slip protection management is very important for safety production (Qian M.G. \& Shi P.W., 2003; Meng X.R. et al., 2007; Pu H., 2011; Ma L.Q. et al., 2011). 


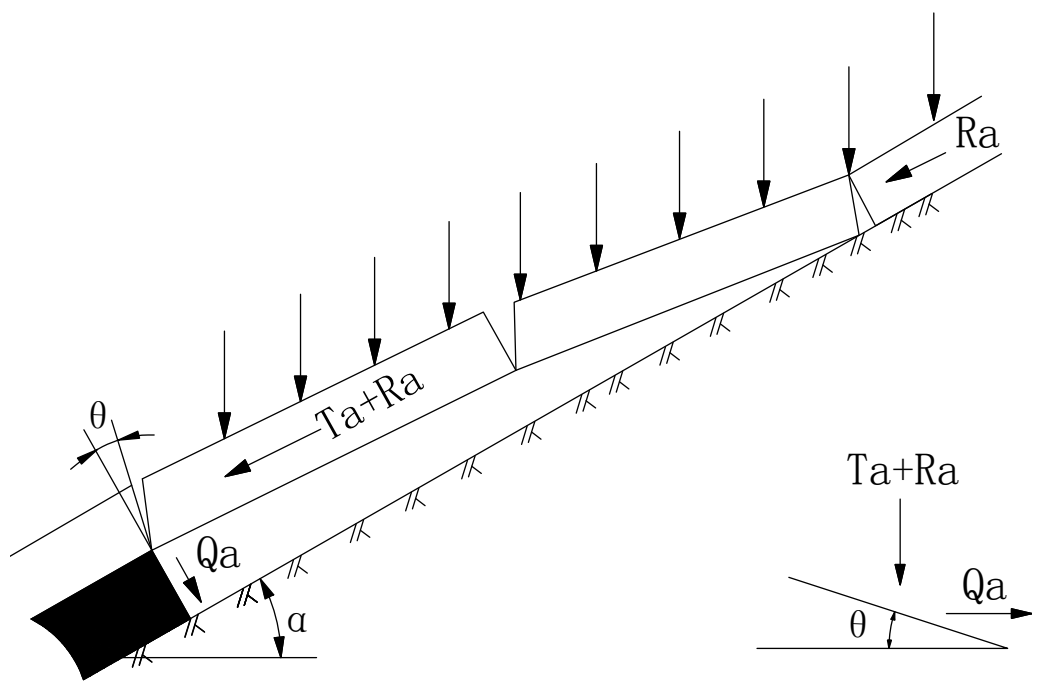

Fig. 3. Grip of rock blocks in downward mining

\section{Support characteristic analysis}

\subsection{Support running characteristic}

In terms of support running characteristic, it means support resistance varies with time in a mining cycle. Generally speaking, the mining cycle includes several types: setting type, one time resistance increasing (RI) type, two times resistance increasing type, three or more times resistance increasing type, resistance decreasing (RD) type, etc.. It can reflect support quality, working condition and roof activities (Yang P.J. et al., 2002). Table 3 shows support RI characteristic in different parts of big depression angle working face through statistic method. Proportion of one time and two times RI is almost same in each part. Proportion of RI for more than two times in upper, middle and lower part is respectively $54.2 \%, 51.5 \%$ and $45.3 \%$, which means loading volatility of supports arranged in upper and middle part are relatively large. Proportion of setting type in lower part is $18.5 \%$, which means stable roof pressure. Average proportion of one time RI, two times RI, three or more times RI is respectively $35.3 \%, 34.4 \%$ and $13.9 \%$, to sum up, average proportion of RI for more than two times is $48.3 \%$, which indicates that loading volatility of support is obvious great.

Properties of resistance increasing (\%)

\begin{tabular}{|c|c|c|c|c|c|}
\hline \hline Part & Setting type & One time RI & Two times RI & Three or more times RI & RD \\
\hline Upper & 7.6 & 34.3 & 37.4 & 16.8 & 3.8 \\
\hline Middle & 1.2 & 34.9 & 36.1 & 15.4 & 12.4 \\
\hline Lower & 18.5 & 36.4 & 30.2 & 9.9 & 4.9 \\
\hline Average & 9.1 & 35.3 & 34.4 & 13.9 & 7.4 \\
\hline
\end{tabular}




\subsection{Frequency distribution of support resistance}

Frequency distribution of support resistance is shown in Fig. 4. It follows normal distribution and loading is mainly distributed in range of $3000 \sim 5500 \mathrm{kN}$, taking a percentage of $60.8 \%$. There is only $2.9 \%$ of loading in $>7000 \mathrm{kN}$ area and $22.5 \%$ in $<3000 \mathrm{kN}$ area. This could signify the high efficiency of support and low margin.

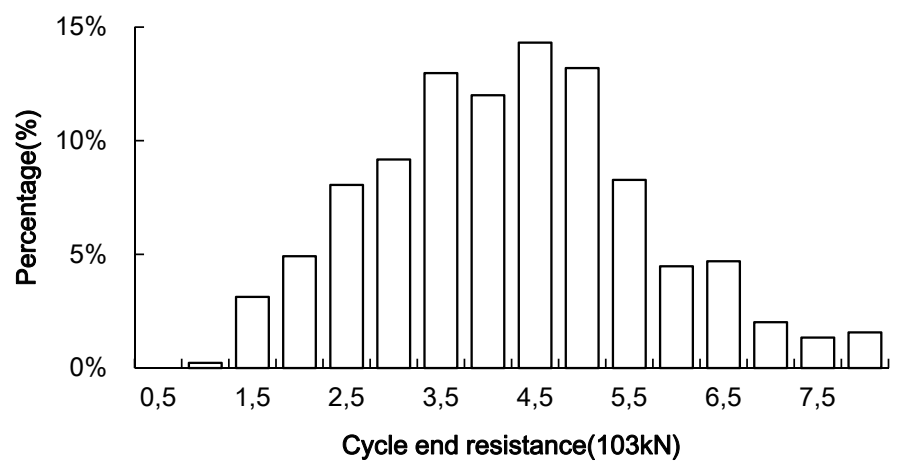

Fig. 4. Frequency distribution of support resistance

\subsection{Distribution characteristic of loading}

Table 4 gives support loading distribution. Consider resistance ratio of vertical shafts in front of support and behind support as the basis for analyzing loading distribution properties. The Fig. 5 lists ratio distributions. During researching and measuring, resistance of vertical shaft behind hydraulic support $\left(\mathrm{R}_{\text {behind }}\right)$ is higher than that of vertical shaft in front of hydraulic support $\left(\mathrm{R}_{\text {front }}\right)$ in general; however, overall area distribution shows obvious imbalance. In strike direction, $\mathrm{R}_{\text {front }}$ and $\mathrm{R}_{\text {behind }}$ are banded mutually and one is greater than the other in phases; in inclination, $\mathrm{R}_{\text {behind }}$ is higher than $R_{\text {front }}$ in lower part of working face and $R_{\text {behind }}$ is less than $R_{\text {front }}$ in upper part of working face. The wide area from upper-middle to lower-middle is transition area.

Distribution of support loading

\begin{tabular}{|c|c|c|c|c|c|c|c|c|}
\hline \hline \multirow{2}{*}{$\begin{array}{c}\text { No. of } \\
\text { support }\end{array}$} & \multicolumn{4}{|c|}{ End resistance [kN/shaft] } & \multicolumn{3}{c|}{ Time weighted resistance [kN/shaft] } \\
\cline { 2 - 9 } & $\mathbf{R}_{\text {front }}$ & $\mathbf{R}_{\text {behind }}$ & $\begin{array}{c}\mathbf{R}_{\text {front }}- \\
\mathbf{R}_{\text {behind }}\end{array}$ & $\begin{array}{c}\mathbf{R}_{\text {front }} / \\
\mathbf{R}_{\text {behind }}\end{array}$ & $\mathbf{R}_{\text {front }}$ & $\mathbf{R}_{\text {behind }}$ & $\begin{array}{c}\mathbf{R}_{\text {front }}- \\
\mathbf{R}_{\text {behind }}\end{array}$ & $\begin{array}{c}\mathbf{R}_{\text {front }} / \\
\mathbf{R}_{\text {behind }}\end{array}$ \\
\hline 8 & 711 & 997 & -286 & $71 \%$ & 539 & 861 & -322 & $63 \%$ \\
\hline 18 & 859 & 951 & -92 & $90 \%$ & 700 & 842 & -142 & $83 \%$ \\
\hline 28 & 937 & 1147 & -210 & $82 \%$ & 754 & 937 & -182 & $81 \%$ \\
\hline 38 & 1211 & 1285 & -74 & $94 \%$ & 983 & 1100 & -117 & $89 \%$ \\
\hline 48 & 1248 & 1213 & 34 & $100 \%$ & 1005 & 999 & 6 & $101 \%$ \\
\hline 58 & 1237 & 1109 & 128 & $112 \%$ & 990 & 924 & 66 & $107 \%$ \\
\hline Average & 1034 & 1117 & -83 & $92 \%$ & 829 & 944 & -115 & $87 \%$ \\
\hline
\end{tabular}


By comparing Fig. 2(b) with Fig. 5, it can be found that resistance before/after support is related to support running resistance. High resistance ratio area in Fig. 5 coincides with low running resistance area in Fig. 2(b), and high running resistance area in Fig. 2(b) also coincides with low resistance ratio area in Fig. 5. Therefore, in big depression angle working face, support loading distribution is related to the overall stress, which means that when support resistance is low, loading is more concentrated in the front of support roof beam; when support resistance is high, loading is more concentrated in the back of support roof beam.

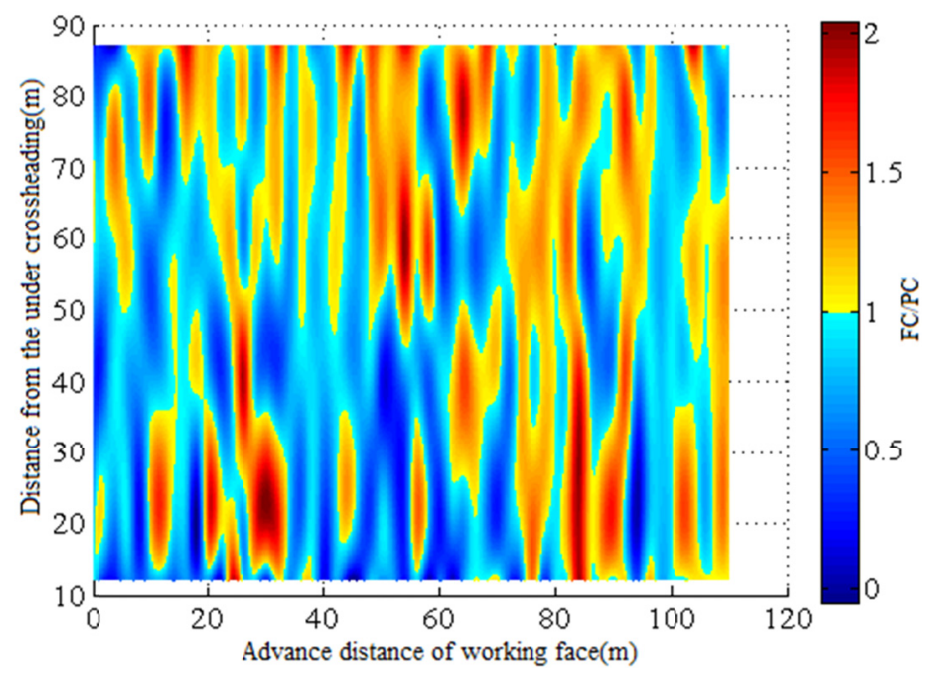

Fig. 5. Resistance ratio of BVS and AVS

\subsection{Relation between advancing speed and hydraulic support loading}

In order to obtain the influence of working face advancing speed on support loading, loading changes of support \#8 under different advancing speeds were measured and statistically analyzed; curves are drawn in Fig. 6.

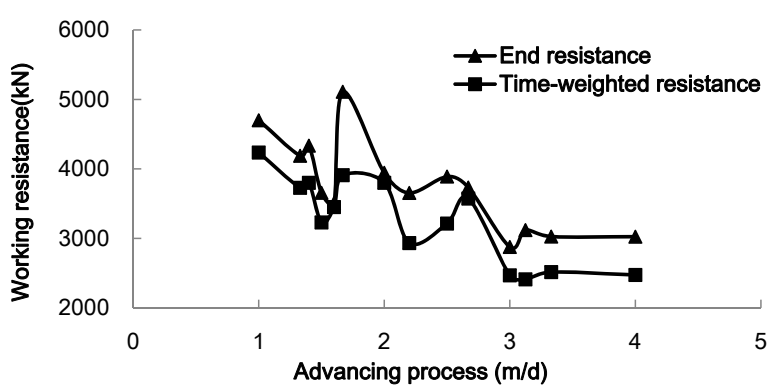

Fig. 6. Relation between advancing speed and support loading 
It is found that advancing speed has a significant influence on support running resistance. When advancing speed is low, resistance is generally high; when advancing accelerates, resistance decreases. For example, when advancing speed is at its lowest state $(1 \mathrm{~m} / \mathrm{d})$, terminal resistance reaches $4700 \mathrm{kN}$ and weighted resistance is $4236 \mathrm{kN}$; when advancing speed reaches the highest $(4 \mathrm{~m} / \mathrm{d})$, terminal resistance is $3025 \mathrm{kN}$, and weighted resistance is $2472 \mathrm{kN}$.

Growing advancing speed within certain range can effectively reduce overlying strata sinkage and support resistance. When advancing speed reaches a certain level (3 4 m/d), influence on support resistance will become weak. In conclusion, considering technical, geological and other condition, advancing process accelerating within certain range $(0 \sim 4 \mathrm{~m} / \mathrm{d})$ will be helpful to control roof better.

\section{Control of hydraulic support location state and stability}

Considering geological condition of Xinji mine \#2, E1108, following methods are applied to control support location state and ensure the stability in mining process with large depression angle:

(1) Pressure reduces along with strike direction, hydraulic support moves to its place for two times instead of normally one time. Meanwhile, basic support force is kept when most of support force is released to ensure roof beam always sticking to roof firmly.

(2) Control drop height strictly in support moving, remove equilibrium jack of the support, and arch up tail end of roof beam to achieve grazing-roof moving with pressure

(3) Control mining height strictly; improve advancing speed to proper value. When increase speed from $1 \mathrm{~m} / \mathrm{d}$ to $3 \sim 4 \mathrm{~m} / \mathrm{d}$ in site, overlying strata sinkage as well as support resistance reduces significantly.

(4) Increase support resistance. Theoretical analysis and practice experience indicate that large support resistance is helpful to keep support stability.

(5) Ensure high friction factors between support and roof/flat.

(6) Strengthen construction quality management.

\section{Conclusion}

(1) Depression angle of working face has a significant influence on support resistance and depression angle is inversely proportional to support resistance; in other word, larger angle area coincides with less support resistance area. Depression angle can be deemed as main factor to law of roof activities when reaches a limit value.

(2) In underhand stoping with large angle, proportion of resistance increasing for more than two times is $48.3 \%$, which indicates that loading volatility of support is obviously great especially in middle and upper part of working face. Besides, support loading distribution is related to the overall stress, which means that, when support resistance is low, loading is more concentrated in the front of support roof beam; when support resistance is high, loading is more concentrated in the back of support roof beam.

(3) Growing advancing speed in proper range created a positive effect. In other words when advancing speed is very low, increasing advancing speed is helpful to roof condition. 


\section{Acknowledgements}

This paper is supported by "Priority Academic Program Development of Jiangsu Higher Education Institutions" and "The Fundamental Research Funds for the Central Universities (2017)."

\section{Reference}

Feng Z.J., Zhang Y.D., Cheng J.Y., et al., 2010. A study on strata-pressure behavior of downward mining in downward \&upward coal face at steep inclination. China Coal. Vol. 36, No. 9, p. 51-54.

Gholamreza Saeedi, Korosh Shahriar, Bahram Rezai et al., 2013. Estimating volume of roof fall in the face of longwall mining by using numerical methods. Arch. Min. Sci. 58, 3, 767-778.

Liu W.Q., Zhu L., 2009. Mode-I-crack compression modeling and numerical simulation for evaluation of in-situ stress around advancing coal workfaces. Mining Science and Technology, Vol. 19, No. 5, p. 569-573.

Li X.Y., Chen P.H.,2004. Study on regularity of structural behaviors around coal face under the shallow-buried loose roof. Chinese Journal of Rock Mechanics and Engineering, Vol. 19, No. 23, p. 3305-3309.

Liu C.Y., Huang B.X., Wu F.F., 2009. Technical parameters of drawing and coal-gangue field movements of a fully mechanized large mining height top coal caving working face. Mining Science and Technology, Vol. 19, No. 5, p. $549-555$.

Ma L.Q., Zhang C.G., Cao X.Q. et al., 2011. Design of Automatic End-Advanced Hydraulic Support in coal face with deep dip angle and large mining height. [In:] 2011 International Conference on Materials Science and Engineering Applications. Xi'an, China: Trans Tech Publications, p. 1524-1530.

Meng X.R., Wen R.F., Liu J.Y., et al. 2011. Research on site measurement of ground behavior in fully mechanized caving mining face in high inclined seam of $1000 \mathrm{~m}$ deep mine. Coal Science and Technology, Vol. 11, No. 35, p. 14-21.

Navid Hosseini, Kazem Oraee, Kourosh Shahriar et al., 2012. Passive seismic velocity tomography and geostatistical simulation on longwall mining panel. Arch. Min. Sci. 57, 1, 139-155.

$\mathrm{Pu}$ H., Zhang J., 2011. Mechanical model of control of key strata in deep mining. Mining Science and Technology, Vol. 21, No. 2, p. 267-272.

Qin B.T., Sun Q.G., Wang D.M., Zhang L.L., Xu Q., 2009. Analysis and key control technologies to prevent spontaneous coal combustion occurring at a fully mechanized caving face with large obliquity in deep mines. Mining Science and Technology, Vol. 19, No. 4, p. 446-451.

Qian M.G., Shi P.W., 2003. Mining Pressure and Strata Control. Xuzhou, China.

Wu Z.J., Ye H.Z., 2008. Key mining technology of underhand mining face with large angle. Coal Mining Technology, Vol. 13, No. 3, p. 32-35.

Yang P.J., Chang X.M., Hu X.J. et al., 2002. The rock pressure law and support loading character at height output height efficiency work face in the thin and medium-thickness seam. Ground Pressure and Strata Control, No. 3, p. 67-73.

Zhang Y.D., Cheng J.Y., Wang X.X. et al., 2010. Thin plate model analysis on roof break of up-dip or down-dip mining stope. Journal of Mining \& Safety Engineering. Vol. 27, No. 4, p. 487-493.

Zhang Z.Y., 2007. Dynamic analysis on stability of hydraulic powered support in deep inclined fully mechanized wall and prevention slips measures. Journal of the China Coal Society, Vol. 32, No. 7, p. 705-709. 